OPEN ACCESS

Edited by:

Joe Shapter,

University of Queensland, Australia

Reviewed by:

Xuhui Sun,

Soochow University, China

Yueli Liu,

Wuhan University of

Technology, China

${ }^{*}$ Correspondence:

Dang Huu Phuc

danghuuphuc@tdtu.edu.vn

Specialty section:

This article was submitted to

Energy Materials,

a section of the journal

Frontiers in Materials

Received: 27 July 2019 Accepted: 14 November 2019 Published: 11 December 2019

Citation:

Tung HT and Phuc DH (2019) Effect of

$\mathrm{Cd}_{1-x} \mathrm{Mn}_{x}$ Se Alloy Thickness on the Optical and Photovoltaic Properties of

Quantum Dot-Sensitized Solar Cells.

Front. Mater. 6:304.

doi: 10.3389/fmats.2019.00304

\section{Effect of $\mathrm{Cd}_{1-\mathrm{x}} \mathrm{Mn}_{\mathrm{x}} \mathrm{Se}$ Alloy Thickness on the Optical and Photovoltaic Properties of Quantum Dot-Sensitized Solar Cells}

\author{
Ha Thanh Tung ${ }^{1}$ and Dang Huu Phuc ${ }^{2,3 *}$ \\ ${ }^{1}$ Institute of Research and Development, Duy Tan University, Da Nang, Vietnam, ${ }^{2}$ Laboratory of Applied Physics, Advanced \\ Institute of Materials Science, Ton Duc Thang University, Ho Chi Minh City, Vietnam, ${ }^{3}$ Faculty of Applied Sciences, Ton Duc \\ Thang University, Ho Chi Minh City, Vietnam
}

In this work, the $\mathrm{Cd}_{1-x} \mathrm{Mn}_{\mathrm{x}} \mathrm{Se}$ alloy was successfully prepared using a successive ionic layer adsorption and reaction method to investigate the layers' effect on the properties of devices while concentration dopant was optimized at 20\% (molar concentrations between $\mathrm{Mn}^{2+}$ and $\mathrm{Cd}^{2+}$ ions in the $\mathrm{Cd}_{1-x} \mathrm{Mn}_{x} \mathrm{Se}$ material). The layers of the $\mathrm{Cd}_{1-x} \mathrm{Mn}_{x} \mathrm{Se}$ alloy play a role in improving the optical, photovoltaic, and electrochemical properties of the solar cells. Hence, the efficiency performance of devices based on the $\mathrm{Cd}_{1-x} \mathrm{Mn}_{x} \mathrm{Se}$ alloy reached $\sim 3.8 \%$. Besides, in order to explain this result, the experimental $I-V$ curve was also used to determine the resistances at the interfaces and the resistance diffusion of the devices. This dynamic resistance can be compared with that of electrochemical impedance spectra.

Keywords: nanomaterials, solar cell, photovoltaic, metal dopant, efficiency

\section{INTRODUCTION}

Semiconductor quantum dots (QDs) have drawn great attention for application in a number of fields due to the optical properties of these materials (Chen et al., 2016; Liu et al., 2016, 2019a,b; Li et al., 2019). Now, nanoparticles prominently become a dye sensitized for the third-generation solar cells because of low-cost fabrication technology, high photostability, the controlled sizes (Peng and Peng, 2001), higher absorption coefficient (Beard Matthew, 2011), and the multiple exciton generation (Sargent, 2005). However, QDSSCs (quantum dot sensitized solar cells) have reached $\sim 13 \%$ performance, which is lower than the theory limits (Jiao et al., 2017). Recently, plenty of QDs [CdS, CdSe, CdTe (Shen et al., 2015), and PbS (Jumabekov et al., 2014)] are widely applied in the QDSSCs because of their unique properties (Duan et al., 2014). It is noticeable that the CdS and CdSe QDs have attracted considerable interest due to their optical property stability (Lin et al., 2014), a higher conduction band than $\mathrm{TiO}_{2}$ (Lee and Lo, 2009), low resistivity (MendozaPerez et al., 2009), and wide absorbed spectrum (Liji Sobhana et al., 2011). However, this result was still low compared with that of dye-sensitized solar cells (DSSCs). So, a CdS/CdSe system was widely investigated due to its wide absorption spectrum, the shift of the absorption peak toward in the visible region, and rising of the conduction band (CB) as the combined CdS and CdSe QDs compared with $\mathrm{TiO}_{2} \mathrm{CB}$. However, the performance based on this system achieved $4 \%$ efficiency (Lee and Lo, 2009), and its performance was still lower than that of DSSCs due to much trapping and recombination at the $\mathrm{TiO}_{2} / \mathrm{QDs} /$ electrolyte triple interfaces (Abdellah et al., 2014). 
In recent times, metal ions doped into the QDs can be replaced by the single QDs and co-sensitized system to reduce achievable recombination (Hodes et al., 1987; Fang et al., 1997, 2011; Gratzel, 2001, 2003; William Yu et al., 2003; Shen and Lee, 2008; Fan et al., 2009; Gimenez et al., 2009; Zhuge et al., 2009; Gonzalez-Pedro et al., 2010; Schmid, 2014; Tan Phat et al., 2018) because it can improve the charge collection and transfer process. In addition, metal ions are famous for their lowest resistance and large mobility. For example, Tan Phat et al. recorded a performance of $4.22 \%$ as $\mathrm{Cu}^{2+}$ ion doped into CdSe QDs because its attractive optical and magnetic properties were more interesting than that of CdSe and PbS QDs (Tan Phat et al., 2018). Their improving properties can be archived by doping metal in QDs like those in Refs. (Hodes et al., 1987; Gratzel, 2001, 2003; Fan et al., 2009; Gimenez et al., 2009; Zhuge et al., 2009; Gonzalez-Pedro et al., 2010) to make contributions to the more absorption photons of photoelectrodes.

Herein, $\mathrm{Mn}^{2+}$ ions were doped on CdSe nanoparticles to study the optical and photovoltaic properties of the QDSSCs. We investigate how changing the thickness of $\mathrm{Cd}_{1-\mathrm{x}} \mathrm{Mn}_{\mathrm{x}}$ Se films affects efficiency performance. Besides, in order to explain this result, the experimental $I-V$ curve was also used to determine the resistances at the interfaces and the resistances diffusion of the devices. This dynamic resistance can be compared with that of electrochemical impedance spectra.

\section{EXPERIMENT}

\section{Materials}

$\mathrm{Na}_{2} \mathrm{SO}_{3}, \mathrm{NaOH}, \mathrm{Cd}\left(\mathrm{CH}_{3} \mathrm{COO}\right)_{2} .2 \mathrm{H}_{2} \mathrm{O}, \mathrm{Zn}\left(\mathrm{NO}_{3}\right)_{2}, \mathrm{Na}_{2} \mathrm{~S} .9 \mathrm{H}_{2} \mathrm{O}$, methanol, $\mathrm{TiCl}_{4}$, and $\mathrm{Mn}\left(\mathrm{CH}_{3} \mathrm{COO}\right)_{2} \cdot 2 \mathrm{H}_{2} \mathrm{O}$ were purchased from Merck and the fluorine-doped tin oxide was from Dyesol.

\section{Preparation \\ $\mathrm{TiO}_{2}$ Films}

The $\mathrm{TiO}_{2}$ paste was deposited onto transparent conducting substrates F-doped $\mathrm{SnO}_{2}$ (FTO) with $7 \Omega \mathrm{cm}^{-2}$ of the sheet resistance. The $\mathrm{FTO} / \mathrm{TiO}_{2}$ film was sintered in air at $500^{\circ} \mathrm{C}$ for $30 \mathrm{~min}$.

\section{$\mathrm{TiO}_{2} / \mathrm{CdS}$ Films}

The $\mathrm{FTO} / \mathrm{TiO}_{2}$ film immersed in $0.1 \mathrm{M} \mathrm{Cd^{2+ }}$ solution [2.66 $\mathrm{g} \mathrm{Cd}\left(\mathrm{CH}_{3} \mathrm{COO}\right)_{2} .2 \mathrm{H}_{2} \mathrm{O}$ was mixed with $100 \mathrm{ml}$ of de-ionized water] followed by $0.1 \mathrm{M} \mathrm{S}^{2-}$ solution $(2.4 \mathrm{~g}$ $\mathrm{Na}_{2} \mathrm{~S} .9 \mathrm{H}_{2} \mathrm{O}$ was dissolved in $100 \mathrm{ml}$ of methanol). All processes were repeated from one to three times (denoted $\mathrm{FTO} / \mathrm{TiO}_{2} / \mathrm{CdS}$ photoelectrode).

\section{$\mathrm{TiO}_{2} / \mathrm{CdS} / \mathrm{Cd}_{1-x} \mathrm{Mn}_{\mathrm{x}} \mathrm{Se}$ Photoelectrode}

The Se powder was mixed with $\mathrm{Na}_{2} \mathrm{SO}_{3}(0.6 \mathrm{M})$ and $100 \mathrm{ml}$ of pure water at $70^{\circ} \mathrm{C}$ for about $7 \mathrm{~h}$. To accommodate the doping of $\mathrm{Mn}$ metal ion, relevant molar concentrations of $0.3 \mathrm{mM}$ of $\mathrm{Mn}\left(\mathrm{CH}_{3} \mathrm{COO}\right)_{2} .2 \mathrm{H}_{2} \mathrm{O}$ were mixed with $\mathrm{Cd}\left(\mathrm{CH}_{3} \mathrm{COO}\right)_{2} .2 \mathrm{H}_{2} \mathrm{O}$ anion source. The SILAR process of CdSe and Mn-doped CdSe QDs was similar to that of CdS except that $15 \mathrm{~min}$ and $50^{\circ} \mathrm{C}$ were required for dipping the $\mathrm{TiO}_{2} / \mathrm{CdS}$ film in the Se aqueous solution. Then, the $\mathrm{FTO} / \mathrm{TiO}_{2} / \mathrm{CdS}$ film was dipped in the above solution for $1 \mathrm{~min}$ before dipping in $\mathrm{Se}^{2-}$ solution for $1 \mathrm{~min}$ at $80^{\circ} \mathrm{C}$ (called 1 layer).

Polysulfide solution was made by dissolving $0.5 \mathrm{M}$ $\mathrm{Na}_{2} \mathrm{~S} .9 \mathrm{H}_{2} \mathrm{O}, 0.2 \mathrm{M} \mathrm{S}$, and $0.2 \mathrm{M} \mathrm{KCl}$ in DI water/methanol (7:3 by volume). The $\mathrm{Cu}_{2} \mathrm{~S}$ counter electrode was synthesized through chemical bath deposition according to a previous publication (Fan et al., 2009). Briefly, $0.24 \mathrm{~g} \mathrm{CuSO}_{4}$ was dissolved in $60 \mathrm{ml}$ of DI in a glass bottle. $\mathrm{N}_{2}$ was bubbled through the water for $10 \mathrm{~min}$ to remove the dissolved oxygen from the system. Then $0.37 \mathrm{~g}$ of $\mathrm{Na}_{2} \mathrm{~S}_{2} \mathrm{O}_{3} .5 \mathrm{H}_{2} \mathrm{O}$ was mixed in the solution, and the color turned to light green. Afterwards, a clean FTO glass was immersed in the solution, with its conductive surface facing down and had an angle against the wall. The system was then settled in the water bath of $90^{\circ} \mathrm{C}$ and kept for $1 \mathrm{~h}$. The $\mathrm{Cu}_{2} \mathrm{~S}$ crystal would directly grow onto the conductive surface of FTO glass. Finally, the as-prepared $\mathrm{Cu}_{2} \mathrm{~S}$-coated FTO glass sample was rinsed with deionized water and dried in air. The post-heat treatment was carried out in an $\mathrm{N}_{2}$ atmosphere at $200^{\circ} \mathrm{C}$ for $30 \mathrm{~min}$ and a structure of device was shown in Figure $\mathbf{1}$.

\section{Characterization}

The scanning electron microscopy (SEM) with a JEOL $7500 \mathrm{~F}$ high-resolution scanning electron microscope was used to determine the morphology of films. The structure of materials were recorded by an X-ray diffraction pattern, Philips model, and the absorption spectrum was investigated by a JASCO V-670. The $I-V$ curve was recorded using simulated AM 1.5 sunlight with an output power of $100 \mathrm{~mW} \mathrm{~cm}^{-2}$. The resistances of QDSSCs were studied by electrochemical impedance spectroscopy (EIS) Series G750.

\section{RESULTS AND DISCUSSION}

Figures 2A-D are the FE-SEM and cross-section of $\quad \mathrm{TiO}_{2} / \mathrm{CdS}(3), \quad \mathrm{TiO}_{2} / \mathrm{CdS}(3) / \mathrm{Cd}_{0.8} \mathrm{Mn}_{0.2} \mathrm{Se}(3), \quad$ and $\mathrm{TiO}_{2} / \mathrm{CdS}(3) / \mathrm{Cd}_{0.8} \mathrm{Mn}_{0.2} \mathrm{Se}(3)$ photoanodes with a $\mathrm{Mn}^{2+}$ concentration of 0.2 and a thickness of three layers, respectively. The porous $\mathrm{TiO}_{2}$ nanoparticles look like a sphere, which can be seen obviously in the inset image with $65 \mathrm{~nm}$ of an average size. Every layer of $\mathrm{TiO}_{2} / \mathrm{CdS}(3), \mathrm{TiO}_{2} / \mathrm{CdS}(3) / \mathrm{Cd}_{0.8} \mathrm{Mn}_{0.2} \mathrm{Se}(3)$,

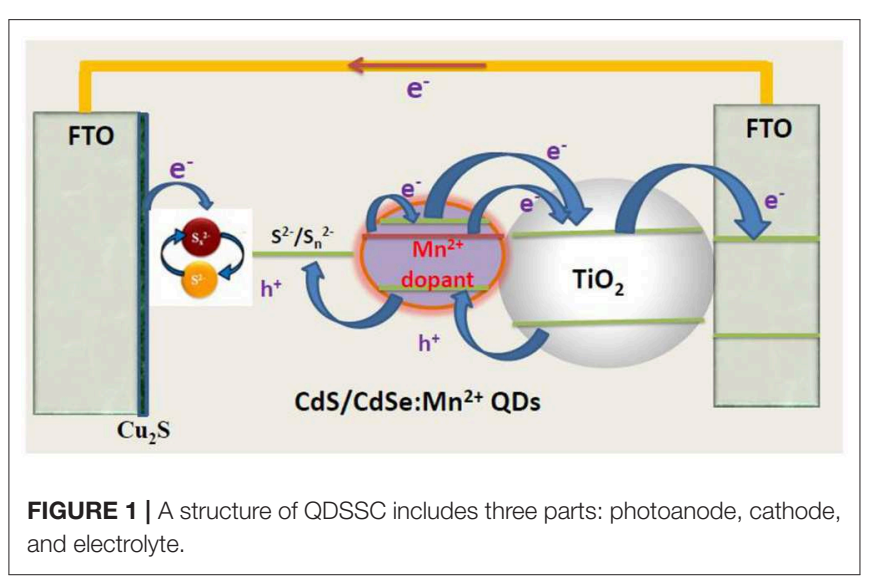


and $\mathrm{TiO}_{2} / \mathrm{CdS}(3) / \mathrm{Cd}_{0.8} \mathrm{Mn}_{0.2} \mathrm{Se}(3)$ photoanodes was determined to be $\sim 11.606,11.750$, and $12.056 \mu \mathrm{m}$ from Figures 2B-D, respectively. Moreover, $0.5 \mu \mathrm{m}$ in Figure $2 \mathrm{C}(0.563 \mu \mathrm{m}$ in Figure 2D) and $11.006 \mu \mathrm{m}$ are the thickness of FTO and the $\mathrm{TiO}_{2} / \mathrm{CdS}$ (3) film without FTO. The energy peaks related to $\mathrm{Ti}$ and $\mathrm{O}$ elements in the $\mathrm{TiO}_{2}$ film and $\mathrm{Cd}$, Se, and $\mathrm{S}$ elements of CdS and CdSe nanocrystal were clearly found in the EDX spectra of $\mathrm{TiO}_{2} / \mathrm{Cd}_{1-\mathrm{x}} \mathrm{Mn}_{\mathrm{x}} \mathrm{Se} / \mathrm{CdSe}$ photoanode. Si and $\mathrm{C}$ energy peaks had been originated from FTO and excessive organic solution remaining in the layer (since the electrodes were sintered in vacuum), respectively. Mn energy peaks came from the anion precursor solution. The EDX spectra confirmed that QDs had been assembled and crystallized on the $\mathrm{TiO}_{2}$ layer (Figure 2E).

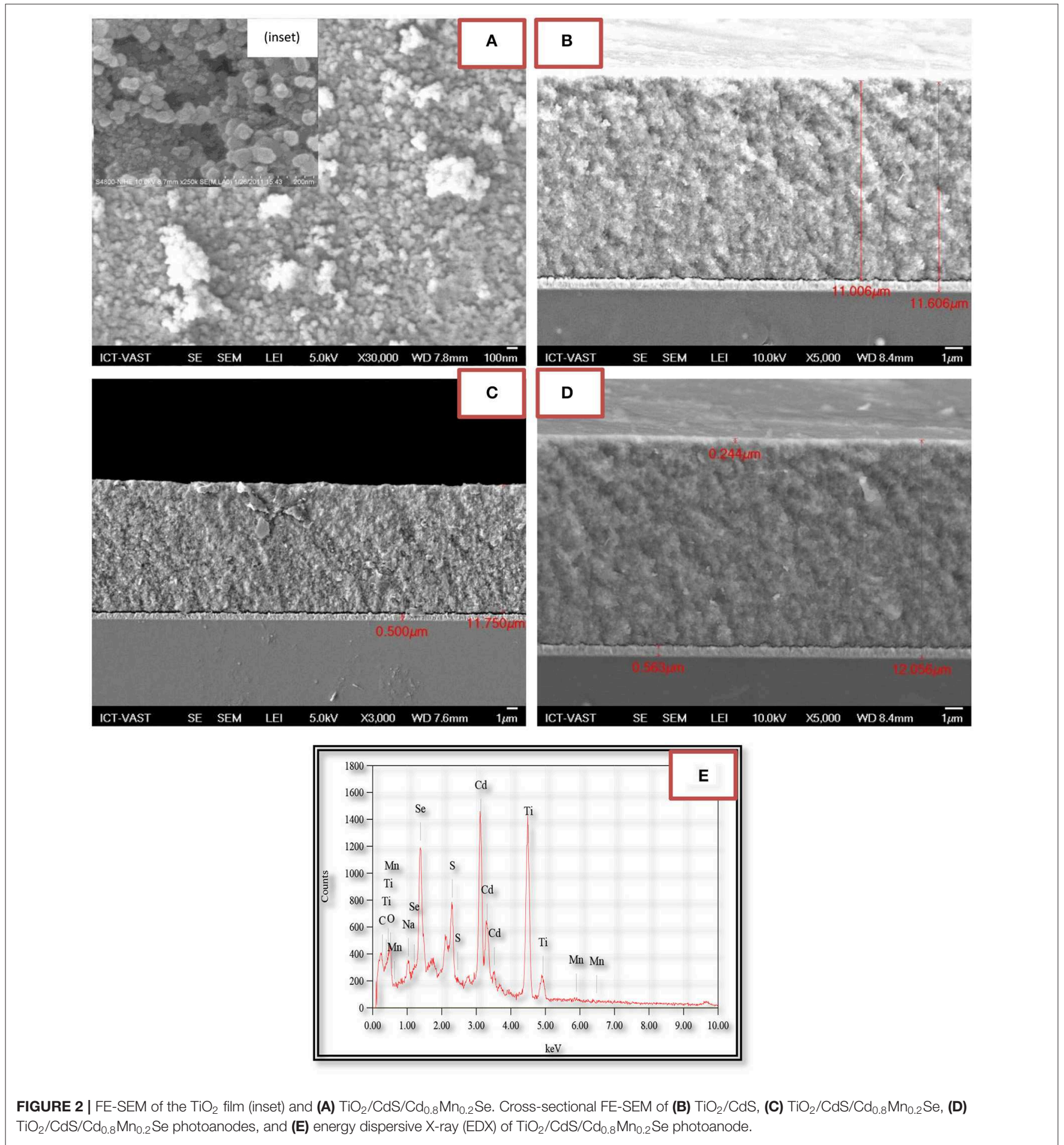


The optical properties of $\mathrm{TiO}_{2} / \mathrm{CdS} / \mathrm{Cd}_{1-\mathrm{x}} \mathrm{Mn}_{\mathrm{x}} \mathrm{Se}$ photoelectrodes were investigated by UV-Vis spectra with different thicknesses (Supplementary Table 1). The red shift is more pronounced with the increase of SILAR cycles due to the growth and thickness of film and attributed to the size quantization effect. This indicates that the high absorption coefficient of CdSe:Mn ${ }^{2+}$ QDs is attributed to $\mathrm{TiO}_{2}$ nanoparticles, which are extended to almost the whole visible region as corresponding to SILAR cycles from 1 to 3 (Figure 3A). However, a decline in overall absorption was observed when SILAR cycle is higher than 3. This can be attributed to the aggregation of CdSe: $\mathrm{Mn}^{2+}$ nanocrystal due to decreasing photocurrent and increase in dynamic resistances (Singh et al., 2008; Bhupendra et al., 2011; Cao et al., 2015; Muthalif et al., 2016). Furthermore, the Tauc plot and additional information on it are shown in Table 1, Supplementary Table 2 and Figure 3B. The bandgap of QDs decreased from $2.04 \mathrm{eV}$ for $\mathrm{Cd}_{0.8} \mathrm{Mn}_{0.2} \mathrm{Se}$ (1) to $1.7 \mathrm{eV}$ for $\mathrm{Cd}_{0.8} \mathrm{Mn}_{0.2} \mathrm{Se}$ (3) QDs. This result shows that there is a strong influence of the doped concentration and thickness on the energy band structure of the CdSe host material (Gopi et al., 2015).

Figure 4A exhibits an alignment energy of photoanode, which includes a dopant energy in the bandgap of CdSe QDs caused by the shift peak, an increasing absorption intensity (shown in Figure 3A), and the $(\alpha h \nu)^{2}$ vs. (hv) curves (shown in Figure $3 \mathbf{B}$ ). The results are also confirmed by the timeresolved photoluminescence spectrum in Figure 4B and the data in Supplementary Table 3 and Table 1. In a similar manner,

TABLE 1 | The parameters obtained from the diode model, UV-Vis, and PL decay.

\begin{tabular}{lcccccccc}
\hline Anodes & $\mathbf{R}_{\mathbf{D}}(\boldsymbol{\Omega})$ & $\mathbf{R}_{\mathbf{d}}(\boldsymbol{\Omega})$ & $\mathbf{R}_{\mathbf{S}}(\boldsymbol{\Omega})$ & $\mathbf{R}_{\mathbf{S H}}(\mathbf{k} \boldsymbol{\Omega})$ & $\mathbf{l} \mathbf{( o}\left(\boldsymbol{\Omega} / \mathbf{c m}^{2}\right)$ & $\mathbf{E}_{\mathbf{g}}(\mathbf{e V})$ & $\boldsymbol{\tau}(\mathbf{n s})$ \\
\hline $\mathrm{Cd}_{0.8} \mathrm{Mn}_{0.2} \mathrm{Se}(1)$ & 48.4 & 795 & 747 & 9.7 & $1.25 \times 10^{-8}$ & 2.04 & 198.1 \\
$\mathrm{Cd}_{0.8} \mathrm{Mnn}_{0.2} \mathrm{Se}(2)$ & 43.2 & 896 & 853 & 13.2 & $2.55 \times 10^{-8}$ & 1.79 & 198.9 \\
$\mathrm{Cd}_{0.8} \mathrm{Mn}_{0.2} \mathrm{Se}(3)$ & 27.38 & 2140 & 2110 & 18.9 & $3.55 \times 10^{-8}$ & 1.70 & 203 \\
$\mathrm{Cd}_{0.8} \mathrm{Mn}_{0.2} \mathrm{Se}(4)$ & 44.76 & 3860 & 3820 & 11.8 & $1.51 \times 10^{-8}$ & 1.78 & 206.5 \\
$\mathrm{Cd}_{0.8} \mathrm{Mn}_{0.2} \mathrm{Se}(5)$ & 67.7 & 2190 & 2120 & 7.09 & $6.23 \times 10^{-8}$ & 1.74 & 200
\end{tabular}

the lifetimes of charges in the $\mathrm{CB}$ of $\mathrm{CdSe}$ nanoparticles were shorter than those of $\mathrm{Cd}_{0.8} \mathrm{Mn}_{0.2} \mathrm{Se}$ QDs. In particular, the lifetimes of charges increase from 198.1 to 206.5 ns when SILAR cycles changed from 1 to 3 . The probability of charge transfer from $\mathrm{Cd}_{0.8} \mathrm{Mn}_{0.2} \mathrm{Se}$ to $\mathrm{CdS}$ and $\mathrm{TiO}_{2}$ was facilitated as large lifetimes. However, a decline in the lifetimes was recorded with loading higher than three layers due to the aggregation of $\mathrm{Cd}_{0.8} \mathrm{Mn}_{0.2}$ Se nanoparticles.

Herein, both the $I-V$ model from Refs. (Thongpron and Kirtikara, 2006; Thanh et al., 2015) and our experimental $I-V$ curves were used to calculate the external dynamic resistance $\left(R_{D}\right)$ and the internal dynamic resistance $\left(R_{d}\right)$, the series resistance $\left(R_{S}\right)$, and the shunt resistance $\left(R_{S H}\right)$ of cells. It is necessary and more important to obtain the reliable characterization in the QDSSCs when the dynamic parameters were determined. We can control and determine the amount of loss mechanism as accurately as possible to improve the efficiency performance in the next work (Sze and $\mathrm{Ng}, 1981$ ).

The photo current density $\left(\mathrm{I}_{\mathrm{ph}}\right)$ and open voltage circuit $\left(\mathrm{V}_{\mathrm{OC}}\right)$ of a solar cell is given by

$$
\begin{aligned}
& I_{p h}=I_{d}+I_{S H} \\
& I_{p h}=I_{o}\left(e^{\alpha V_{O C}}-1\right)+\frac{V_{O C}}{R_{S H}}
\end{aligned}
$$

with $\alpha=\frac{q}{n k T}$.

$$
\begin{aligned}
R_{D} & =\frac{V_{1}-V_{2}}{I_{2}-I_{1}} \\
\text { and } \quad R_{d} & =\frac{1}{\alpha\left(I_{2}-I_{1}\right)} \ln \left[\frac{I_{p h}+I_{o}-I_{1}}{I_{p h}+I_{o}-I_{2}}\right]
\end{aligned}
$$

$\mathrm{R}_{\mathrm{D}}$ and $\mathrm{R}_{\mathrm{d}}$ are the external dynamic resistance and internal dynamic resistance of the equivalent circuit of solar cells.

The shunt resistance $\left(\mathrm{R}_{\mathrm{SH}}\right)$ was obtained:

$$
R_{S H}=\frac{V_{O C}}{I_{p h}-I_{o}\left(e^{\alpha V_{o}}-1\right)}
$$

where $\mathrm{V}_{\mathrm{o}}$ is the initial voltage.
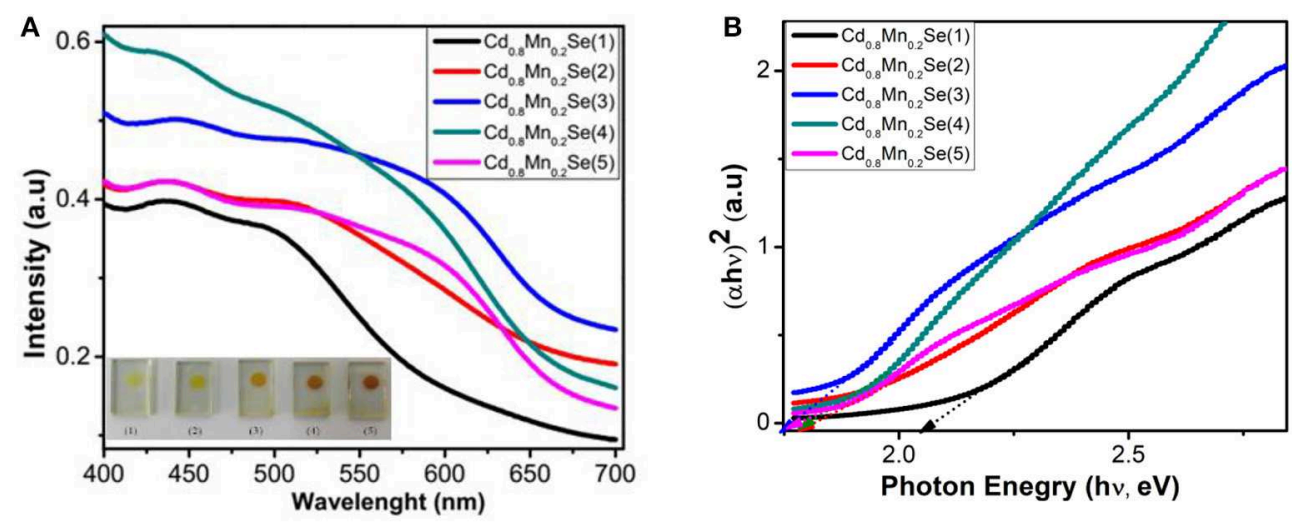

Photon Enegry (hv, eV)

FIGURE 3 | (A) UV-Vis and (B) $(\alpha h v)^{2}$ vs (hv) curves of $\mathrm{TiO}_{2} / \mathrm{CdS} / \mathrm{Cd}_{0.8} \mathrm{Mn}_{0.2}$ Se photoanodes. 

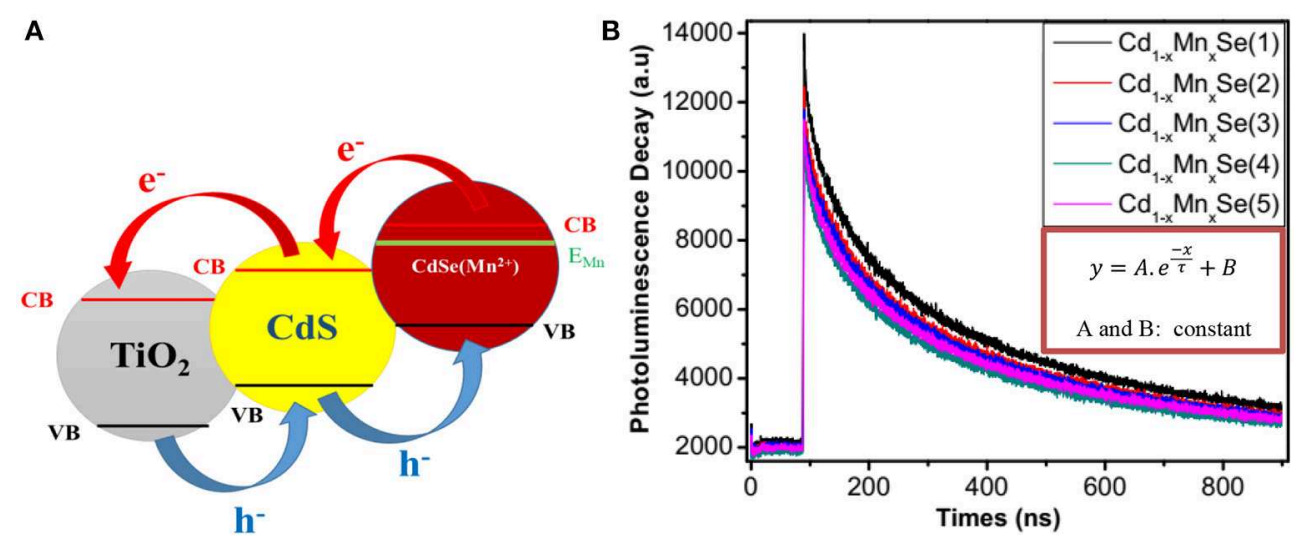

FIGURE 4 | (A) Alignment energy and (B) time - resolved Photoluminescence of $\mathrm{TiO}_{2} / \mathrm{CdS}(3) / \mathrm{Cd}_{0.8} \mathrm{Mn}_{0.2} \mathrm{Se}$ photoanodes.

In order to determine the performance, we recorded the I-V curves of QDSSCs with the different layers of $\mathrm{Cd}_{1-\mathrm{x}} \mathrm{Mn}_{\mathrm{x}} \mathrm{Se} \mathrm{QDs}$, which is shown in Figure 5. In comparison, It is obvious that the optimized thickness of $\mathrm{Cd}_{1-\mathrm{x}} \mathrm{Mn}_{\mathrm{x}} \mathrm{Se}$ (3 layers) QDs made contributions to boost the efficiency of QDSSCs ( 3.8\%) (Supplementary Table 4). This result is suitable to that of UV-Vis, lifetime, and IES.

On the whole, our view is that resistances showed up as the increasing SILAR cycles of $\mathrm{Cd}_{1-\mathrm{x}} \mathrm{Mn}_{\mathrm{x}}$ Se films (Sze and $\mathrm{Ng}$, 1981). The result agrees well with that of the $I-V$ curve $(3.8 \%$ of efficiency). Furthermore, $\mathrm{R}_{\mathrm{SH}}$ was calculated from Equation 5 , and it depended on the technology process. The values of $\mathrm{R}_{\mathrm{SH}}$ are large, corresponding to a good QDSSC. Looking at Table 1, it reveals that the $\mathrm{R}_{\mathrm{SH}}$ of $\mathrm{CdS} / \mathrm{Cd}_{1-\mathrm{x}} \mathrm{Mn}_{\mathrm{x}} \mathrm{Se}$ cosensitized $\mathrm{TiO}_{2}$ is the largest. This is also confirmed by the long lifetimes of charges with loading SILAR cycles more than 3. In brief, the dynamic resistances, saturated current intensity, lifetimes of charges, and bandgap depend on the thickness of $\mathrm{TiO}_{2} / \mathrm{CdS}(3) / \mathrm{Cd}_{0.8} \mathrm{Mn}_{0.2} \mathrm{Se}(3)$ with the highest efficiency of $3.8 \%$.

Figure 6A gives information about the circuit, which corresponds to the QDSSCs. Figure 6B shows the experimental Nyquist plots of devices corresponding to the resistance at the surface of the polyelectrolyte/counter electrode (denoted as $R_{c t 1}$ ) and the diffuse resistance in the $\mathrm{TiO}_{2}$ film and $\mathrm{TiO}_{2} / \mathrm{QDs}$ surface (denoted as $\mathrm{R}_{\mathrm{ct} 2}$ ) (Veerathangam et al., 2017). The lifetime of excited electron $\left(\tau_{n}\right)$ is determined from Figure $4 \mathrm{~B}$, and the capacitance $\left(c_{\mu}\right)$ can be determined by $c_{\mu}=$ $\frac{\tau_{n}}{R_{c t 2}}$ and listed in Supplementary Table 5 and Table 2. As a rule, the $\mathrm{Cd}_{0.8} \mathrm{Mn}_{0.2} \mathrm{Se}$ (1), $\mathrm{Cd}_{0.8} \mathrm{Mn}_{0.2} \mathrm{Se}$ (2), $\mathrm{Cd}_{0.8} \mathrm{Mn}_{0.2} \mathrm{Se}$ (3), $\mathrm{Cd}_{0.8} \mathrm{Mn}_{0.2} \mathrm{Se}$ (4), and $\mathrm{Cd}_{0.8} \mathrm{Mn}_{0.2} \mathrm{Se}$ (5) photoelectrodes have significantly changed in the photovoltaic because layers played a role in the recombination process. It is obvious that the thicker the film is, the larger resistance becomes. From Table 2, the resistances of four to five layers are larger than the resistance of three layers, while the excited electrons' lifetime and capacitances are much lower (Omid et al., 2015). Above all, the performance

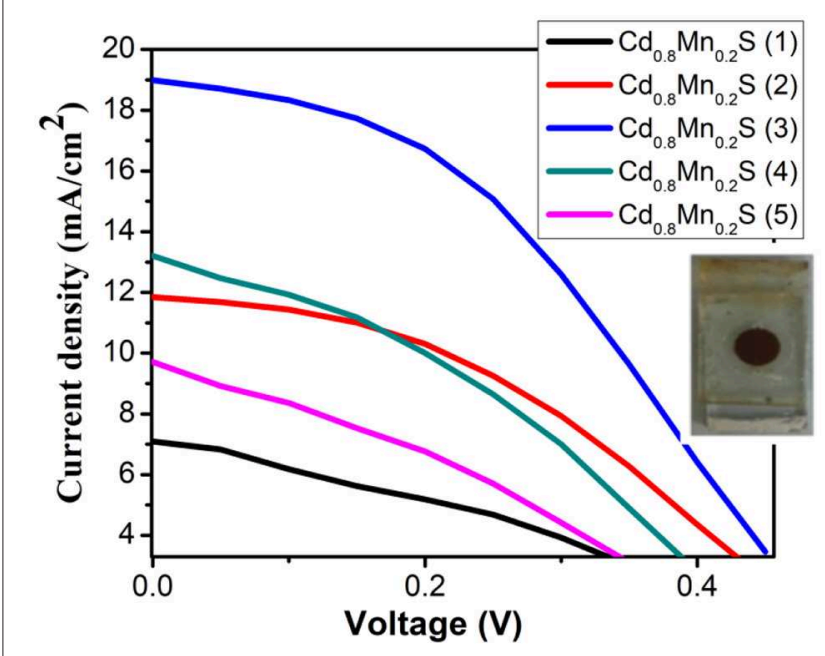

FIGURE 5 | I-V curves of QDSSCs based on the $\mathrm{TiO}_{2} / \mathrm{CdS} / \mathrm{Cd}_{1-x} \mathrm{Mn}_{\mathrm{x}} \mathrm{Se}$ photoanodes.

increased because of a rise in $\mathrm{CB}$ of the $\mathrm{Cd}_{1-\mathrm{x}} \mathrm{Mn}_{\mathrm{x}} \mathrm{Se}$ QDs and a shift of the absorption peak after doping (shown in Figure 4A).

Table 1 illustrates the value of dynamic resistances from one illuminated $I-V$ curve and EIS with the same conditions. Looking at the graph, it is immediately obvious that they depend on the SILAR cycles of deposition of $\mathrm{Cd}_{0.8} \mathrm{Mn}_{0.2} \mathrm{Se}$ with the same rules. In this case, the results show that the $R_{D}, R_{d}, R_{c t 1}$, and $R_{c t 2}$ are the smallest with loading at three SILAR cycles of deposition, but the value of $R_{S H}$ is the largest. We noted larger $R_{S H}$ indicates a better quality of QDSSCs. The trend of the recombination resistance $\left(\mathrm{R}_{\mathrm{c} 2}\right)$ of all devices can clearly be analyzed when the SILAR cycles of deposition are changed. The $R_{D}, R_{d}$, and $R_{c t 2}$ are characterized by the dynamic processes, dynamic resistances, and resistance transfer at surfaces of $\mathrm{TiO}_{2} / \mathrm{QDs}$. With the 
A

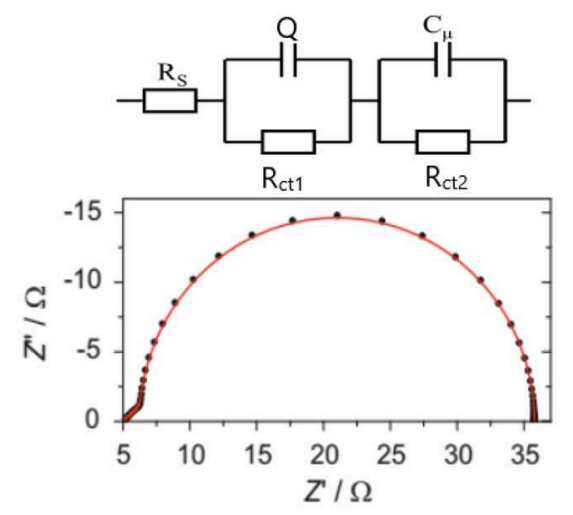

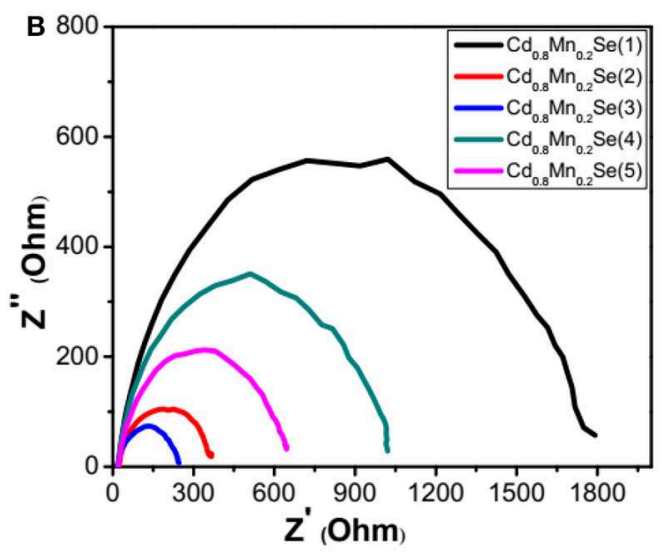

FIGURE 6 | (A) The theoretical circuit and theoretical Nyquist plot and (B) the experimental Nyquist plot of solar cells.

TABLE 2 | The parameters of I-V curves and electrochemical impedance spectra.

\begin{tabular}{lcccccccc}
\hline Anodes & $\boldsymbol{J}_{\mathbf{S C}}\left(\mathbf{m A} / \mathbf{c m}^{2}\right)$ & $\mathbf{F F}$ & $\boldsymbol{V}_{\mathbf{~ o c}}(\mathbf{V})$ & $\eta(\%)$ & $\mathbf{R}_{\mathbf{S}}(\boldsymbol{\Omega})$ & $\mathbf{R}_{\mathbf{c t 1}}(\boldsymbol{\Omega})$ & $\mathbf{R}_{\mathbf{c t} 2}(\boldsymbol{\Omega})$ \\
\hline $\mathrm{Cd}_{0.8} \mathrm{Mn}_{0.2} \mathrm{Se}(1)$ & 7.09 & 0.34 & 0.48 & 1.17 & 20.87 & 908.4 & 815.6 \\
$\mathrm{Cd}_{0.8} \mathrm{Mn}_{0.2} \mathrm{Se}(2)$ & 11.84 & 0.37 & 0.53 & 2.37 & 22.55 & 283.4 & 65.51 \\
$\mathrm{Cd}_{0.8} \mathrm{Mn}_{0.2} \mathrm{Se}(3)$ & 19 & 0.38 & 0.52 & 3.8 & 16.98 & 204.5 & 24.65 \\
$\mathrm{Cd}_{0.8} \mathrm{Mn}_{0.2} \mathrm{Se}(4)$ & 13.04 & 0.37 & 0.52 & 2.39 & 20.26 & 444.9 & 190.7 \\
$\mathrm{Cd}_{0.8} \mathrm{Mn}_{0.2} \mathrm{Se}(5)$ & 9.71 & 0.30 & 0.47 & 1.42 & 19.35 & 780.1 & 566.7 \\
\hline
\end{tabular}

smallest $R_{D}, R_{d}$, and $R_{c t 2}$, the optimum energy conversion efficiency was obtained $\sim 3.8 \%$ at three cycles of deposition (Supplementary Table 6). This is completely suitable with the results of UV-Vis and lifetimes.

\section{CONCLUSIONS}

To summarize, photoelectrodes such as $\mathrm{TiO}_{2} / \mathrm{CdS} / \mathrm{Cd}_{1-\mathrm{x}} \mathrm{Mn}_{\mathrm{x}} \mathrm{Se}$ have successfully been prepared using SILAR. The thickness of the $\mathrm{Cd}_{1-\mathrm{x}} \mathrm{Mn}_{\mathrm{x}}$ Se film affected the optical and photovoltaic properties of QDSSCs. The $J-V$ curves show that the conversion efficiency is improved due to the optimized thickness at three cycles and $\mathrm{Cd}_{1-\mathrm{x}} \mathrm{Mn}_{\mathrm{x}} \mathrm{Se}$ QDs. In addition, this result is also confirmed by the shift of absorption toward to the visible region, increasing lifetimes, and reducing charge recombination at the polyelectrolyte/counter electrode, $\mathrm{TiO}_{2} / \mathrm{Cd}_{0.8} \mathrm{Mn}_{0.2} \mathrm{Se} /$ polyelectrolyte interfaces, and diffusion

\section{REFERENCES}

Abdellah, M., Marschan, R., Žıdek, K., Messing, M. E., Abdelwahab, A., Chábera, P., et al. (2014). Hole trapping: the critical factor for quantum dot sensitized solar cell performance. J. Phys. Chem. 118, 25802-25808. doi: $10.1021 /$ jp5086284

Beard Matthew, C. (2011). Multiple exciton generation in semiconductor quantum dots. J. Phys. Chem. Lett. 2, 1282-1288. doi: 10.1021/jz200166y resistance in $\mathrm{TiO}_{2}$ films. As a result, QDSSCs exhibited a high conversion efficiency of $3.8 \%$.

\section{DATA AVAILABILITY STATEMENT}

All datasets generated for this study are included in the article/Supplementary Material.

\section{AUTHOR CONTRIBUTIONS}

HT and DP conceived and planned the experiments and carried out the experiments, contributed to sample preparation, took the lead in writing the manuscript. They also performed the experiments about the structural materials and contributed to the analysis of the new results of the manuscript.

\section{ACKNOWLEDGMENTS}

The authors would like to thank the University of Science, VNUHCM, Vietnam.

\section{SUPPLEMENTARY MATERIAL}

The Supplementary Material for this article can be found online at: https://www.frontiersin.org/articles/10.3389/fmats. 2019.00304/full\#supplementary-material 
antimony sulfide nanocrystals with high yield. Nanoscale 8, 5146-5152. doi: 10.1039/C5NR09097K

Duan, J., Tang, Q., He, B., and Yu, L. (2014). Electrochim. Acta 139 381-385. doi: 10.1016/j.electacta.2014.06.165

Fan, S. Q., Cao, R. J., Xi, Y. X., Gao, M., Wang, M. D., and Kima, D. H. (2009). CdSe quantum dots as co-sensitizers of organic dyes in solar cells for red-shifted light harvesting. J. Optoelectr. Adv. Mater. Rap Commun. 10, 1027-1033.

Fang, B., Kim, M., Fan, S. Q., Kim, J. H., Wilkinson, D., Ko, J., et al. (2011). Facile synthesis of open mesoporous carbon nanofibers with tailored nanostructure as a highly efficient counter electrode in CdSe quantum-dot-sensitized solar cells. J. Mater. Chem. 21, 8742-8748. doi: 10.1039/c1jm10113g

Fang, J., Wu, J., Lu, X., Shen, Y., and Lu, Z. (1997). Sensitization of nanocrystalline $\mathrm{TiO}_{2}$ electrode with quantum sized CdSe and $\mathrm{ZnT}_{\mathrm{c}} \mathrm{P}_{\mathrm{c}}$ molecules. Chem. Phys. Lett. 270, 145-51. doi: 10.1016/S0009-2614(97)00333-3

Gimenez, S., Mora-Sero, I., Macor, L., Guijarro, N., Lana-Villarreal, T., and Gomez, R. (2009). Improving the performance of colloidal quantum-dot-sensitized solar cells. Nanotechnology 20:295204. doi: 10.1088/0957-4484/20/29/295204

Gonzalez-Pedro, V., Xu, X., Mora-Sero, I., and Bisquert, J. (2010). Modeling high-efficiency quantum dot sensitized solar cells. ACS Nano 4, 5783-90. doi: $10.1021 / \mathrm{nn} 101534 \mathrm{y}$

Gopi, C. V. V. M., Bae, J.-H., Venkata-Haritha, M., Kim, S.-K., Lee, Y.-S., Sarat, G., et al. (2015). One-step synthesis of solution processed time-dependent highly efficient and stable PbS counter electrodes for quantum dot-sensitized solar cells. RSC Adv. 5, 107522-107532. doi: 10.1039/C5RA22715A

Gratzel, M. (2001). Photoelectrochemical cell. Nature 414, 338-344. doi: $10.1038 / 35104607$

Gratzel, M. (2003). Dye-sensitized solar cells. J. Photochem. Photobiol. 4, 145-53. doi: 10.1016/S1389-5567(03)00026-1

Hodes, G., Albu-Yaron, A., Decker, F., and Motisuke, P. (1987). Three-dimensional quantum-size effect in chemically deposited cadmium selenide films, Phys. Rev. 36, 4215-4221. doi: 10.1103/PhysRevB.36.4215

Jiao, S., Du, J., Du, Z., Long, D., Jiang, W., Pan, Z., et al. (2017). Nitrogen-doped mesoporous carbons as counter electrodes in quantum dot sensitized solar cells with a conversion efficiency exceeding 12\%. J. Phys. Chem. Lett. 8, 559-564. doi: 10.1021/acs.jpclett.6b02864

Jumabekov, A. N., Siegler, T. D., and Cordes, N. (2014). Comparison of solid-state quantum-dot-sensitized solar cells with exsitu and in situ grown $\mathrm{PbS}$ quantum dots. J. Phys. Chem. 118, 25 853-856. doi: 10.1021/jp5051904

Lee, Y. L., and Lo, Y. S. (2009). Highly efficient quantum-dot-sensitized solar cell based on co-sensitization of CdS/CdSe. Adv. Funct. Mater. 19, 604-609 doi: 10.1002/adfm.200800940

Li, Y., Wang, L., Li, Z., Liu, Y., Peng, Z., Zhou, M., et al. (2019). Synthesis and photocatalytic property of $\mathrm{V}_{2} \mathrm{O}_{5} @ \mathrm{TiO}_{2}$ core-shell microspheres towards gaseous benzene. Catal. Today 321, 164-171. doi: 10.1016/j.cattod.2018. 02.029

Liji Sobhana, S. S., Vimala Devi, M., and Sastry, T. P. (2011). CdS quantum dots for measurement of the size-dependent optical properties of thiol capping. J. Nanopart. Res. 13:1747. doi: 10.1007/s11051-0109934-1

Lin, L., Zou, X., Zhou, H., and Teng, G. (2014). Cu-doped-CdS/In-DopedCdS cosensitized quantum dot solar cells. J. Nanomat. 2014:314386. doi: $10.1155 / 2014 / 314386$

Liu, Y., Wang, H., Chen, K., Yang, T., Yang, S., and Chen, W. (2019b). Acidic site-assisted ammonia sensing of Novel $\mathrm{CuSbS}_{2}$ quantum dots/reduced graphene oxide composites with an ultralow detection limit at room temperature. ACS Appl. Mater. Interfaces 11, 9573-9582. doi: 10.1021/acsami. 8 b20830

Liu, Y., Wang, L., Wang, H., Xiong, M., Yang, T., and Zakharova, G. S. (2016). Highly sensitive and selective ammonia gas sensors based on $\mathrm{PbS}$ quantum dots $/ \mathrm{TiO}_{2}$ nanotube arrays at room temperature. Sens. Actuat. 236, 529-536. doi: 10.1016/j.snb.2016.06.037

Liu, Y., Zhou, M., Zhang, W., Chen, K., Mei, A., Zhang, Y., et al. (2019a). Enhanced photocatalytic properties of $\mathrm{TiO}_{2}$ nanosheets@2D layered black phosphorus composite with high stability under hydro-oxygen environment. Nanoscale 12, 5674-5683. doi: 10.1039/C8NR10476J

Mendoza-Perez, R., Sastre-Hernandez, J., Puente, G., and Vigil-Galan, O. (2009). Solar energymater. Solar Cells 8:79. doi: 10.1016/j.solmat.2008.09.016

Muthalif, M. P. A., Lee, Y. S., Sunesh, C. D., Kim, H. J., Choe, Y. (2016). Enhanced photovoltaic performance of quantum dot-sensitized solar cells with a progressive reduction of recombination using $\mathrm{Cu}$-doped $\mathrm{CdS}$ quantum dots. Appl. Surf. Sci. 396, 582-589. doi: 10.1016/j.apsusc.2016. 10.200

Omid, A., Salavati-Niasari, M., Farangi, M. (2015). Enhancement of dye-sensitized solar cells performance by core shell Ag@ organic (organic=2-nitroaniline, PVA, 4-choloroaniline and PVP): effects of shell type on photocurrent. Electrochim. Acta 153, 90-96. doi: 10.1016/j.electacta.2014.11.195

Peng, Z. A., and Peng, X. (2001). Formation of high-quality CdTe, CdSe, and CdS nanocrystals using CdO as precursor. J. Am. Chem. Soc. 123, 183-184. doi: $10.1021 / \mathrm{ja} 003633 \mathrm{~m}$

Sargent, E. (2005). Infrared quantum dots. Adv. Mater. 17, 515-522. doi: 10.1002/adma.200401552

Schmid, G. (2014). Nanoparticles: From Theory to Application. Weinheim: Wiley$\mathrm{VCH}$.

Shen, X., Jia, J., and Lin, Y. (2015). Enhanced performance of CdTe quantum dot sensitized solar cell via anion exchanges. J. Power Sour. 277, 215-218. doi: 10.1016/j.jpowsour.2014.12.022

Shen, Y.-J., and Lee, Y.-L. (2008). Assembly of CdS quantum dots onto mesoscopic $\mathrm{TiO}_{2}$ films for quantum dot-sensitized solar cell application, Nanotechnology 19:045602. doi: 10.1088/0957-4484/19/04/045602

Singh, S. B., Limaye, M. V., Lalla, N. P., and Kulkarni, S. K. (2008). Copperion-induced photoluminescence tuning in CdSe nanoparticles. J. Lumin. 128, 1909-1912. doi: 10.1016/j.jlumin.2008.05.022

Sze, S. M., and Ng, K. K. (1981). Physics of Semiconductor Devices. New York, NY: John Willey \& Sons.

Tan Phat, N., Tung Ha, T., Thao Nguyen, T., Phuong Ho, N., Dat Huynh, T., and Vinh Lam, Q., et al. (2018). Effect of Cu2+ ions doped on the photovoltaic features of CdSe quantum dot sensitized solar cells. Electrochim. Acta 20, 16-23. doi: 10.1016/j.electacta.2018.06.046

Thanh, T. H., Quang, V. L., and Huynh Thanh, D. (2015). Determination of the dynamic resistance of the quantum dots solar cells by one I-V curve and electrochemical impedance spectra. Solar Energy Mater. Solar Cells 143, 269-274. doi: 10.1016/j.solmat.2015.07.007

Thongpron, J., and Kirtikara, K. (2006). "Voltage and frequency dependent impedances of monocrystalline, polycrystalline and amorphous silicon solar cells," 2006 IEEE 4th World Conference on Photovoltaic Energy Conference (Waikoloa, HI: IEEE), May 7-12. doi: 10.1109/WCPEC.2006.279922

Veerathangam, K., Pandian, M. S., and Ramasamy, P. (2017). Photovoltaic performance of Ag-doped CdS quantum dots for solar cell application. Mater. Res. Bull. 94, 371-377. doi: 10.1016/j.materresbull.2017.06.024

William Yu, W., Qu, L., Guo, W., and Peng, X. (2003). Experimental determination of the extinction coefficient of CdTe, CdSe, and CdS nanocrystals. Chem. Mater. 15, 2854-2860. doi: 10.1021/cm034081k

Zhuge, F., Li, X., Gao, X., Gan, X., and Zhou, F. (2009). Synthesis of stable amorphous $\mathrm{Cu}_{2} \mathrm{~S}$ thin film by successive ion layer adsorption and reaction method. Mater. Lett. 63, 652-654. doi: 10.1016/j.matlet.2008.12.010

Conflict of Interest: The authors declare that the research was conducted in the absence of any commercial or financial relationships that could be construed as a potential conflict of interest.

Copyright (C) 2019 Tung and Phuc. This is an open-access article distributed under the terms of the Creative Commons Attribution License (CC BY). The use, distribution or reproduction in other forums is permitted, provided the original author(s) and the copyright owner(s) are credited and that the original publication in this journal is cited, in accordance with accepted academic practice. No use, distribution or reproduction is permitted which does not comply with these terms. 